\title{
POLA ASUH MAKAN (JENIS DAN FREKUENSI) “PROMPTING OR ENCOURAGEMENT TO EAT" BERKAITAN DENGAN KONSUMSI SAYUR PADA ANAK PRASEKOLAH BERUSIA 4 - 6 TAHUN
}

\author{
Elen Rambu Kahi Leba ${ }^{1,}$ Ronasari Mahaji Putri ${ }^{2}$, Sulasmini ${ }^{3}$ \\ ${ }^{1,2,3}$ Fakultas Ilmu Kesehatan Universitas Tribhuwana Tunggadewi Malang \\ Email : putrirona@gmail.com
}

\begin{abstract}
Abstrak
Banyak dijumpai anak usia pra sekolah yang sulit untuk mengkonsumi sayur, walaupun sebenarnya jika digali bahwa sayuran ini memberikan manfaat yang besar bagi kesehatan anak.Orangtua berperan penting dalam mendorong, memfasilitasi anak mengkonsumsi sayur. Mengetahui hubungan pola asuh makan "prompting or encouragement to eat" dengan konsumsi sayur pada anak prasekolah berusia 4-6 tahun menjdi tujuan dalam penelitian ini. Desain penelitian korelatif dengan pendekatan cross sectional. Populasi adalah semua ibu dan anak prasekolah berusia 4-6 tahun di TK Dharma Wanita Persatuan, Tlogomas Kecamatan Lowokwaru Kota Malang berjumlah 43 orang, dengan sampel 35 orang menggunakan teknik Simple Random Sampling. Kuesioner berbentuk checklist dan food frequency merupakan instrument yang digunakan dalam penelitian ini, dengan uji Chi Square Test. Hasil penelitian membuktikan sebagian besar ibu (60\%) memiliki pola asuh makan "prompting or encouragement to eat" yang baik; sebagian besar $(56,7 \%)$ anak prasekolah berusia 4-6 tahun mengkonsumsi sayur secara. Uji statistik menunjukkan kaitan pola asuh makan "prompting or encouragement to eat" dengan konsumsi sayur anak prasekolah berusia 4-6 tahun di TK Dharma Wanita Persatuan Tlogomas Kecamatan Lowokwaru Kota Malang $\left(p_{\text {value }}=(0,006)<(0,05)\right.$. Direkomendasikan untuk peneliti selanjutnya dengan menambahkan faktor-faktor determinan dari pola asuh makan "prompting or encouragement to eat" dengan konsumsi sayur pada anak.
\end{abstract}

Kata Kunci: $\quad$ Pola Asuh, Prompting or Encouragement To Eat, Konsumsi, Prasekolah

\section{Abstract}

There are many pre-school children who find it difficult to consume vegetables. Even though vegetables provide many benefits for the health of the child's body if consumed regularly. The eating habits in children cannot be separated from the role of parents, especially mothers, in encouraging children to consume vegetables or prompting or encouragement to eat. The purpose of this study was to determine the relationship between prompting or encouragement to eat eating patterns with vegetable consumption in preschool children aged 4-6 years. Correlative research design with cross sectional approach. The population is all mothers and preschool children aged 4-6 years in TK Dharma Wanita Persatuan Tlogomas, Lowokwaru District Malang City totaling 43 people, with a sample of 35 people using the Simple Random Sampling technique.The research instrument used a questionnaire in the form of a checklist and food frequency. Data analysis using Chi Square Test. The results showed that most of the mothers (60\%) had a good "prompting or encouragement to eat" diet; Most (56.7\%) preschool children aged 4-6 years consume vegetables. Statistic test shows that there is a significant relationship between prompting or encouragement to eat eating patterns with vegetable consumption in preschool children aged 4-6 years at TK Dharma Wanita Persatuan Tlogomas, Lowokwaru District, Malang City (pvalue $=(0.006)<(0.05)$ It is recommended for further researchers to add the determinant factors of prompting or encouragement to eat with vegetable consumption in children.

Keywords: Parenting, Prompting or Encouragement To Eat, Consumption, Preschools

\section{Pendahuluan}

Pertumbuhan dan perkembangan anak menjadi bagian tahap dasar perkembangan selanjutnya. Masa ini sangat pendek (critical period) atau masa keemasan (golden gold) (Adriana,
2013).Wong (2008) mengungkapkan bahwa disebut anak usia pra sekolah jika berada di rentang usia 3-5 tahun atau 3672 bulan, berciri khas tersendiri dalam pertumbuhan dan perkembangannya. Rohan HH., (2013) menambahkan bahwa 
pertumbuhan adalah bertambah besarnyanya sel diseluruh bagian tubuh dan pematangan fungsi organ tubuh pada setiap anak

Mengkonsumsi makanan sehat menyokong perkembangan dan pertumbuhan anak. Makanan sehat yang mengandung unsur karbohidrat,protein, mineral dan vitamin merupakan makanan yang baik (Budhi Susanto, 2014). Sayur sebagai bagian sumber gizi mikro juga termasuk buah memberikan manfaat yang baik. Keduanya berperan dalam proses metabolism, sebagai zat pengatur, berfungsi juga sebagai antibodi yang mampu menurunkan resiko penyakit kronis. Indira (2015) menguatkan bahwa sayur penting dikonsumsi anak usia prasekolah karena sedang berada di masa emas kehidupan.

Adanya fenomena banyak anak tidak memiliki kesadaran untuk mengkonsumsi sayur, walaupun pada kenyataannya sayur ini sangat baik untuk kesehatan (Putri et al., 2017). Orangtua menjadi tokoh utama dalam keluarga , terutama ibu dalam menanamkan kebiasaan serta mendorong anak untuk konsumsi sayur, yang dikenal dengan istilah prompting or encouragement to eat. Untuk itu pola asuh ibu dalam memberikan dorongan makan sayur kepada anak sangat penting untuk membentuk kebiasaan makan sayur sejak anak usia dini (Indira, 2015).

Rendahnya konsumsi sayur pada anak masih menjadi masalah bagi orangtua. Putriana, MI., Putriana, (2010) menunjukkan rendahnya konsumsi sayur (73,5 gram/hari) dan konsumsi buah (58,6 gram/hari). Didukung Winastyo, Kumboyono S, (2013) yang menemukan hasil sama, yakni sebagian besar $(62 \%)$ anak mengkonsumsi sayur rendah, dan hanya 38\% anak yang mengkonsumsi keseluruhan sayur. Senada dengan Wunga, AAT., Ardiyani, VM., Ahmad, (2019) yang menemukan hampir seluruhnya $\quad(80,8 \%)$ berperilaku konsumsi sayur yang kurang. Dikatakan kurang karena angka asupannya masih jauh dari standar rekomendasi yang dianjurkan WHO dan Pedoman Gizi Seimbang (PGS) (300gram/ hari). Candrawati, E., Wiarsih., W., 2014) juga sependapat bahwa rendahnya asupan sayur anak yakni mencapai $83,1 \%$. Demikian juga praktik dalam pemberian makan anak diketahui mayoritas ibu (64\%) kurang menyediakan sayur dan buah dengan baik. Hasil penelitian ini juga menemukan 94,7\% keluarga yang kurang menyediakan sayur lebih besar dibanding keluarga yang menyediakan sayur. Rendahnya konsumsi sayur pada anak juga tidak lepas dari kurangnya pengetahuan anak tentang sayur. Putri, RM., Maemunah, (2017) mengungkapkan bahwa sejumlah hampir keseluruhan anak berpengetahuan sayur kurang, berpengetahuan jenis sayur yang kurang 83,7\%, serta kurang berpengetahuan tentang manfaat sayur $55,1 \%$. Dari berbagai data diatas, perlu diketahui factor yang mempengaruhi rendahnya konsumsi sayur anak salah satunya yakni pola asuh ibu.

Pola asuh makan sebagai bagian dari intervensi orangtua terhadap anak. Menurut Sarwono (2010) pola asuh sebagai bentuk sikap atau bentuk interaksi orangtua untuk memberikan perlindungan ,memenuhi kebutuhan, membimbing anak, mendidik anak dalam kehidupan keseharian. Pola asuh ini termasuk di dalamnya adalah pola asuh makan. Pola asuh makan oleh ibu, terbagi menjadi 4 tipe dimana setiap ibu pasti akan menerapkan satu dari keempat tipe ini, yakni otoriter, demokratis, pengabaian, permisif. Yumni, dkk (2017) mengungkapkan bahwa keempat tipe tersebut merupakan kombinasi demandingness (D) (seberapa besar peran orang tua dalam menuntut anak untuk makan, mengontrol jumlah dan jenis asupan anak), dan aspek responssiveness (R) (seberapa besar peran orang tua dalam mendampingi anak dan tanggap terhadap kebutuhan anak terkait makan), sehingga dapat dikatakan bahwa setiap 
tipe mempunyai tujuan yang sama yakni pola asuh pemberian makan berisiko untuk meningkatkan keteraturan makan sayur pada anak usia prasekolah.

Pujiyati, dkk (2010) membuktikan bahwa status gizi balita (1-5tahun) dikaitkan dengan pola asuh ibu dalam pemberian makan. Didukung pula Indira (2015) yang menyimpulkan bahwa berbagai hal yang turut mempengaruhi praktek pemberian sayur dan buah oleh ibu yakni banyak sedikitnya informasi ibu tentang sayur dan buah, budaya mendukung konsumsi sayur, kebiasaan menyediakan sayur oleh ibu. Senada dengan Karaki, (2016) yang mengungkapkan bahwa perilaku sulit makan pada anak dikaitkan dengan pola asuh ibu. Diperkuat pula oleh Loya, dkk (2017) yang membuktikan bahwa terjadinya stunting pada anak dihubungkan dengan pola asuh makan pada balita usia 6-12 bulan. Penelitian lain yakni Beko, K., dkk (2018) yang juga meyakinkan bahwa tinggi rendahnya konsumsi sayur anak prasekolah dikaitkan praktik diet dalam keluarga. Pola makan anak prasekolah bergantung bagaimana pola asuh ibu dalam penyediaan makanan yang sehat dan bergizi, sesuai dengan kebutuhannya (Restianti, 2009)

Berdasarkan studi pendahuluan yang terhadap 10 orang siswa-siswi di TK Dharma Wanita Persatuan Tlogomas Kecamatan Lowokwaru Kota Malang diketahui bahwa semua ibu menyiapkan sayur untuk anak namun tidak mendorong anak untuk mengkonsumsi sayur tersebut dikarenakan anak tidak mau konsumsi sayur, dan ibu hanya menuruti kemauan anak-anak dengan alasan dari pada anak tidak makan. Alasan ini yang melatarbelakangi peneliti mengambil judul hubungan pola asuh makan "prompting or encouragement to eat" dengan konsumsi sayur pada anak usia prasekolah

Metode Penelitian
Desain penelitian menggunakan pendekatan cross sectional. Populasi sebanyak 43 orang ibu dan anak usia 4-6 tahun di TK Dharma Wanita Persatuan Tlogomas Kecamatan Lowokwaru Kota Malang, dengan menggunakan rumus Slovin didapatkan sampel 30 orang ,melalui teknik Simple Random Sampling Kuesioner sebagai teknik dalam mengumpulkan data penelitian ini, dengan uji Chi-Square dan bantuan SPSS.

\section{Hasil}

Dari Tabel 1 dikemukakan sebagian anak prasekolah berusia 4-6 tahun sebesar $(53,3 \%)$ berjenis kelamin lakilaki; seluruh anak prasekolah berusia 4-6 tahun ; hampir setengahnya dari responden sebesar $(46,7 \%)$ merupakan ibu dengan usia 30-39 tahun; sebagian besar sebesar (53,3\%) yaitu ibu berpendidikan SMA; sebagian besar responden sebesar $(56,7 \%)$ yaitu sebagai IRT (ibu rumah tangga); seluruh ibu memiliki media TV, radio; hampir seluruh responden sebesar $(93,3 \%)$ yaitu ibu mengatakan memiliki ketertarikan pada sayur, dan seluruh ibu mengatakan selalu menyediakan sayur untuk anaknya dan seluruh ibu mengatakan adanya ketersediaan sayur di rumah.

\section{Karakteristik Responden}

\begin{tabular}{lcc}
\hline \multicolumn{1}{c}{ Kategori } & f & \% \\
\hline Jenis Kelamin & & \\
Anak & & \\
$\quad$ Perempuan & 14 & 46,7 \\
$\quad$ Laki-laki & 16 & 53,3 \\
\hline
\end{tabular}

\begin{tabular}{lcc}
\hline Usia Ibu & & \\
$\quad \begin{array}{l}20-29 \\
\text { tahun }\end{array}$ & 10 & 33,3 \\
$30-39$ & & \\
tahun & 14 & 46,7 \\
$\quad>39$ tahun & 6 & 20 \\
\hline Tingkat & & \\
Pendidikan Ibu & & \\
$\quad$ SD & - & - \\
SMP & 2 & 6,7 \\
SMA & 16 & 53,3
\end{tabular}




\begin{tabular}{lcc}
$\begin{array}{l}\text { Perguruan } \\
\text { Tinggi (S1) }\end{array}$ & 12 & 40 \\
\hline Jenis Pekerjaan & & \\
Ibu & & \\
$\quad$ IRT & 17 & 56,7 \\
$\quad$ Wiraswasta & 10 & 33,3 \\
$\quad$ PNS & 3 & 10 \\
\hline Media yang & & \\
Dimiliki : TV & & \\
$\quad$ Ya & 30 & 100 \\
$\quad$ Tidak & - & - \\
\hline Media yang & & \\
Dimiliki : Radio & & \\
$\quad$ Ya & 30 & 100 \\
$\quad$ Tidak & - & - \\
\hline Menyediakan & & \\
Sayur & & \\
$\quad$ Ya & 30 & 100 \\
$\quad$ Tidak & - & - \\
\hline
\end{tabular}

\section{Pola Asuh Makan "Prompting Or} Encouragement To Eat",

Tabel 2 digambarkan mayoritas 18 orang $(60 \%)$ ibu menerapkan pola asuh makan "prompting or encouragement to eat".

Tabel 2. Distribusi Frekuensi Untuk Pola Asuh Makan "Prompting $\mathrm{Or}$ Encouragement To Eat" di TK Dharma Wanita Persatuan Tlogomas Kecamatan Lowokwaru Kota Malang.

\begin{tabular}{lcr}
\hline \multicolumn{1}{c}{ Pola Asuh } & $\mathrm{f}$ & $\%$ \\
\hline $\begin{array}{l}\text { Pola Asuh } \\
\text { Makan “Prompting } \\
\text { or Encouragement } \\
\text { to Eat" }\end{array}$ & & \\
$\begin{array}{l}\text { Bukan Pola Asuh } \\
\text { Makan "Prompting } \\
\text { or Encouragement } \\
\text { to Eat" }\end{array}$ & 18 & 60 \\
\hline Total & 12 & \\
\hline
\end{tabular}

\section{Konsumsi Sayur}

Tabel 3. Distribusi Frekuensi Untuk Konsumsi Sayur Pada Anak Prasekolah Berusia 4-6 Tahun

\begin{tabular}{|c|c|c|}
\hline $\begin{array}{l}\text { Konsumsi } \\
\text { Sayur }\end{array}$ & $\mathrm{f}$ & $\%$ \\
\hline Teratur & 17 & 56,7 \\
\hline Tidak Teratur & 13 & 43,3 \\
\hline Total & 30 & 100 \\
\hline
\end{tabular}

\section{Hubungan Pola Asuh Makan "Prompting or Encouragement to Eat" Dengan Konsumsi Sayur}

Uji Chi Square $\left(\chi^{2}\right)$ menunjukkan nilai $\rho_{\text {value }}=0,006 \quad(<0,05)$ yang artinya artinya ada hubungan pola asuh makan "prompting or encouragement to eat" dengan konsumsi sayur pada anak prasekolah

\section{Pembahasan}

\section{Pola Asuh Makan "Prompting Or Encouragement To Eat"}

Sebagian besar ibu dan anak prasekolah berusia $4-6$ tahun memiliki pola asuh makan "prompting or encouragement to eat". Data ini menunjukkan bahwa sebagian besar orangtua telah melakukan pola asuh makan yang baik pada anaknya, yakni mendorong, memuji dan juga memastikan anak mengkonsumsi makanan yang sudah disiaokan oleh ibunya.

Sebagian besar ibu dan anak prasekolah telah menerapkan pola asuh makan "prompting or encouragement to eat" yang dimungkinkan dipengaruhi beberapa faktor diantaranya (Tridhonanto, Ali., 2014) meliputi: tingkat pendidikan ibu, pengalaman dalam mengasuh anak; orangtua yang membentuk pola pengasuhan anak; dan juga riwayat cara pola asuh orangtua sebelumnya yang dianggap berhasil, dan kemudian diterapkan pula kehidupan anaknya.

Pola asuh ibu sangat menentukan kebiasaan makan anak. Penerapan pola asuh pada anak, tentunya dianggap yang 
terbaik oleh ibu. Jelas disampaikan Tridhonanto, Ali (2014) bahwa tampilnya sikap orangtua sebelumnya dalam mendidik anak akan menjadi penyebab munculnya upaya pengasuhan. Sejalan dengan Sarwono, (2010) bahwa ibu akan berinteraksi dengan anak untuk memberikan perlindungan, membimbing, serta mendidik dengan cara terbaik. Sependapat pula dengan Ayun (2017) bahwa setiap keluarga memiliki pola asuh yang berbeda dalam mendidik seorang anak dan biasanya diturunkan oleh pola asuh yang diterima dari orang tua sebelumnya. Pola asuh dapat didefinisikan sebagai bentuk pola interaksi antara anak dengan orangtua yang kompleks meliputi pemenuhan kebutuhan fisik (seperti minum, makan dan lain-lain) dan kebutuhan psikologis (seperti kasih saying, rasa aman, kasih sayang dan lain-lain), serta sosialisasi berbagai norma di masyarakat agar anak dapat bersama lingkungannya. Apapun yang dilakukan ibu, akan berpengaruh pada keadaan anak termasuk juga dalam hal makan. Sesuai Pujiyati, dkk (2010) yang membuktikan status gizi anak berkaitan dengan pola asuh pemberian nutrisi anak.

\section{Konsumsi Sayur Pada Anak Prasekolah Berusia 4 - 6 Tahun}

Sebagian ibu dan anak prasekolah berusia $4-6$ tahun telah mengkonsumsi sayur secara teratur sebesar dan mengatakan frekuensi mengkonsumsi sayur dilakukan secara teratur. Data ini menunjukkan bahwa mayoritas anak di TK Dharma wanita mempunyai kebiasaan yang baik dan teratur dalam mengkonsumsi berbagai jenis sayur.

Pengetahuan anak memegang peran penting dalam konsumsi makanan.Pengetahuan anak yang kurang baik tentang sayur, dimungkinkan akan memberikan dampak penolakan anak terhadap sayur. Sriwahyuni., dkk (2013) menyatakan bahwa pengetahuan yang dimiliki anak tentang manfaat mengkonsumsi sayur mempengaruhi pola perilaku dan pola konsumsi. Selain itu juga adanya faktor internal dan eskternal anak turut mempengaruhi tingkat konsumsi satur anak (Khomsan Ali, 2008). Faktor internal disini antara lain: preferensi makanan, keluarga dan faktor pendapatan. Preferensi makanan menjadi faktor penentu konsumsi makanan termasuk sayur dan buah. Sependapat dengan Putri, RM., dkk (2020) yang menemukan bahwa ada kaitan antara pengetahuan dengan preferensi dan sikap dalam mengkonsumsi sayur. Didukung pula oleh Tarigan (2020) yang menyatakan ada hubungan antara preferensi, konsumsi sayur, dan ketersediaan sayur, buah di rumah $(\mathrm{p}=$ $0.006, \mathrm{RP}=2.79)$. Sependapat dengan Santoso (2013) yang menyimpulkan pola preferensi ,asupan makanan anak dibentuk berdasarkan pengalaman makan dan kebiasaan makanan yang diberikan oleh ibu, pola konsumsi anak didapat melalui pengalaman awal akan makanan serta praktik orangtua saat memberikan makan anak. Preferensi terhadap makanan adalah sikap seseorang menyatakan tidak suka atau suka terhadap makanan, dan ini juga dipengaruhi oleh orang tua. Keluarga memberikan konstribusi utama kebiasaan makan anak dan pemberian makanan yang aman, bergizi untuk anak merupakan tanggung jawab orangtua. Orangtua berperan dalam membentuk kebiasaan makan dan menjadi preferensi makanan bagi anak-anaknya. (Lien N, Lytle LA ( 2001) ; Kelder SH, Perry CL, Klepp KI, (1994) menguatkan bahwa Preferensi rasa yang dikembangkan di masa kanak-kanak dapat berlanjut sepanjang hidup.

Faktor lain yang berpengaruh dalam konsumsi sayur adalah pendapatan keluarga. Dengan keluarga mempunyai pendapatan, maka memungkinkan sebuah keluarga mempunyai daya beli dan menyediakan sayur serta buah sebagai bagian hidangan keluarga. Ketersediaan 
sayur, buah sebagai menu konsumsi keluarga sangat penting serta diversifikasi pangan dapat memperbaiki mutu gizi pangan seseorang yaitu menyediakan berbagai jenis pangan ditingkat keluarga. Sependapat dengan Amanaturrohim (2015) yang mengungkapkan adanya pengaruh pendapatan dan konsumsi rumah tangga dengan kesejahteraan keluarga baik parsial maupun secara simultan. Senada dengan Hanum (2018) yang menyimpulkan bahwa jumlah tanggungan keluarga, pendapatan dan pendidikan berpengaruh terhadap konsumsi rumah tangga di Seuneubok Rambong. Didukung Miller V, etc (2016) yang mengungkapkan bahwa konsumi sayur dan buah di sleuruh dunia rendah, dan terkait dengan keterjangkauan yang rendah akan sayur dan buah. Serta Ren Y, Li H, (2019) menyimpulkan bahwa keragaman makanan memainkan peran penting dalam menjelaskan dampak konsumsi makan.

Konsumsi makan anak juga dipengaruhi oleh faktor eksternal. Berbagai faktor eksternal yang dimaksud antara lain pengaruh teman sebaya, dan pengaruh media massa. Pengaruh teman sebaya turut menentukan baik buruknya konsumsi makan anak. Pengaruh teman sebaya mampu memberikan penerimaan / pemilihan makan ataupun penolakan terhadap jenis makanan tertentu. Sejalan dengan Virlita (2015) yang menyimpulkan bahwa aktivitas di luar rumah, teman sebaya, tersedianya buah , sayur di rumah mempengaruhi kebiasaan konsumsi sayur. Pesan media juga memberikan andil dalam kesukaan dan pemilihan manan anak, yakni iklan mempengaruhi anak prasekolah dengan sangat mudah sehingga anak akan meminta untuk mengkonsumsinya dan dengan menjadikannya sebagai penganti buah dan sayur. Sependapat dengan Lwin MO,etc (2017)yang mengungkapkan bahwa konsumsi makan dipengaruhi secara positif oleh paparan media siaran di antara anak-anak, dan media memainkan peran kunci dalam mempengaruhi konsumsi makanan. Sejalan pula dengan Boyland EJ (2015) yang menyimpulkan bahwa paparan iklan makanan di televisi meningkatkan asupan makanan pada anak-anak. Seirama penelitian yang dilakukan oleh Indira (2015) yang menemukan bahwa praktek ibu melalui menyediakan sayur buah dalam keluarga mempengaruhi konusmsi anak. Sejalan pula dengan Karaki (2016) yang membuktikan pola asuh makan balita stunting usia 6-12 bulan di Kabupaten Sumba Tengah Nusa Tenggara Timur dan pola asuh makan yang salah pada balita usia 6-12 bulan menyebabkan stunting.

\section{Hubungan Pola Asuh Makan "Prompting or Encouragement to Eat" Dengan Konsumsi Sayur}

Prompting or encouragement to eat berhubungan signifikan dengan konsumsi sayur pada anak prasekolah berusia 4-6 tahun. Pola asuh makan "prompting or encouragement to eat" sebagai pola asuh dengan mendorong anak makan sayur, memastikan anak makan sayur dan membiasakan anak makan sayur pada pada anak prasekolah berusia 4-6 tahun khususnya. Karaki (2016) menemukan kaitan pola asuh dengan perilaku sulit makan anak usia prasekolah (3-5 tahun) di TK Desa Paleton Kecamatan Mofoinding Minahasa Selatan. Juga sesuai penelitian yang dilakukan oleh Loya, dkk (2017) bahwa pola asuh pemberian makan pada balita usia 6-12 bulan yang salah berpotensi menyebabkan terjadinya stunting.

Blissett (2011) menyimpulkan bahwa gaya pemberian makan orang tua, yang mengacu pada teknik atau perilaku orang tua tertentu untuk mempengaruhi asupan makanan anak, dapat menjadi faktor utama dalam menjelaskan bagaimana orang tua mempengaruhi pola makan anak dan bahkan berat badan mereka. Diperkuat oleh O'Connor TM etc 
(2010)menyampaikan bahwa Penelitian telah menunjukkan bahwa gaya memberi makan orang tua dapat dikaitkan dengan konsumsi buah dan sayuran dan status berat badan anak-anak. Hughes SO, etc (2007) mengungkapkan bahwa gaya makan orang tua juga telah dikaitkan dengan asupan buah dan sayur masa kanak-kanak . asupan lemak dan / atau gula yang tinggi (Hennessy E,etc. 2012) dan berat badan (Moens E, Braet C, 2007). Pola asuh ibu adalah sikap/ perlakukan orangtua dalam memberikan perlindungan, dalam memenuhi kebutuhan, mendidik, serta membimbing anak dalam kehidupan keseharian (Sarwono, 2010). Ada 4 jenis pola asuh anak yaitu: otoriter , demokratis, , permisif, serta uninvolved. Pola asuh otoriter ini membatasi serta memaksa, orangtua membuat berbagai aturan yang wajid ditaati anak, berdampak pada anak menjadi penurut dan cenderung menutup diri. Pola asuh demokratis lebih mendorong anak mandiri dengan sedikit kebebasan namun terkontrol. Pola asuh permisif melibatkan anak-anaknya, cenderung membiarkan tanpa memberikan kendali, membuat anak menjadi manja tugas perkembangan terganggu (Santrock, 2011). Sedangkan pola asuh uninvolved yakni pola asuh tidak responsif, mengabaikan anak, kurang terlibat dengan anak, secara social anak kurang cakap, mempunyai pengendalian diri yang buruk, tidak kemandirian dan tidak termotivasi untuk berprestasi (Santrock, 2011).

\section{Kesimpulan}

Penelitian tentang hubungan pola asuh makan "prompting or encouragement to eat" dengan konsumsi sayur pada anak prasekolah berusia 4-6 tahun di TK Dharma Wanita Persatuan Tlogomas Kecamatan Lowokwaru Kota Malang, menyimpulkan bahwa:

1. Sebagian besar ibu yang mempunyai anak prasekolah berusia 4-6 tahun di TK Dharma Wanita Persatuan
Tlogomas Kecamatan Lowokwaru Kota Malang memiliki pola asuh makan "prompting or encouragement to eat".

2. Sebagian anak prasekolah berusia 4-6 tahun di TK Dharma Wanita Persatuan Tlogomas Kecamatan Lowokwaru Kota Malang mengkonsumsi sayur secara teratur.

3. Ada hubungan pola asuh makan "prompting or encouragement to eat" dengan konsumsi sayur pada anak prasekolah berusia 4-6 tahun di TK Dharma Wanita Persatuan Tlogomas Kecamatan Lowokwaru Kota Malang dengan $\left(\rho_{\text {value }}=0,006\right)$.

\section{Saran}

Direkomendasikan untuk melakukan penelitian lanjutan dengan menambahkan faktor-faktor determinan dari pola asuh makan "prompting or encouragement to eat" dengan konsumsi sayur pada anak.

\section{Referensi}

Adriana, D. (2013). Tumbuh Kembang \& Terapi Bermain pada Anak. Salemba Medika.

Amanaturrohim, H. (2015). PENGARUH PENDAPATAN DAN KONSUMSI RUMAH TANGGA TERHADAP KESEJAHTERAAN KELUARGA PETANI PENGGARAP KOPI DI KECAMATAN CANDIROTO KABUPATEN TEMANGGUNG. https://lib.unnes.ac.id/23506/1/7101 411096.pdf

Ayun, Q. (2017). Pola Asuh Orang Tua dan Metode Pengasuhan alam Membentuk Kepribadian Anak. Journal STAIN Kudus. Journal STAIN Kudus, 5(1). http://journal.stainkudus.ac.id/index. php/thufula/article/download/2421/p df.

Badan Pusat Statistik/BPS. (2017). Buletin Pemantauan Ketahanan Pangan.

Beko, K., Candrawati, E., Ariani, N. (2018). Hubungan Praktik Diet 
Keluarga Dengan Tingkat Konsumsi Sayur dan Buah Pada Anak Usia Pra Sekolah Di RA Pesantren Al Madaniyah Landungsari Kabupaten Malang. Nursing Nes: Jurnal Ilmiah Keperawatan, 3(1). https://publikasi.unitri.ac.id/index.ph p/fikes/article/view/793

Blissett. (2011). Relationships between parenting style, feeding style and feeding practices and fruit and vegetable consumption in early childhood. Appetite., 57(3), 826831. 10.1016/j.appet.2011.05.318.

Boyland EJ, W. R. (2015). No TitleFood advertising to children and its effects on diet: review of recent prevalence and impact data. Pediatr Diabetes, 16(5), 331-337. doi: 10.1111/pedi.12278. Epub 2015 Apr 21. PMID: 25899654.

Budhi Susanto. (2014). Fakta Buah dan Sayur Beracun. Cemerlang Publishing, Yogyakarta.

Candrawati, E., Wiarsih., W., S. (2014). Ketersediaan Buah Dan sayur Dalam keluarga Sebagai Strategi Intervensi Peningkatan Konsumsi Buah dan Sayur Anak Usia Pra Sekolah. Care: Jurnal Ilmiah Ilmu Kesehatan., 2(3). https://jurnal.unitri.ac.id/index.php/c are/article/view/216/217

Hanum, N. (2018). Pengaruh Pendapatan, Jumlah Tanggungan Keluarga Dan Pendidikan Terhadap Pola Konsumsi Rumah Tangga Nelayan. JURNAL SAMUDRA EKONOMIKA, 2(1).

https://core.ac.uk/download/pdf/327 251951.pdf

Hennessy E , Hughes SO, Goldberg JP, H. R. (2012). Economos CD: Permissive parental feeding behavior is associated with an increase in intake of Low-nutrientdense foods among American children living in rural communities. J Acad Nutr Diet., 112(1), 142-148. 10.1016/j.jada.2011.08.030.

Hughes SO, Patrick H, Power TG, Fisher
JO, Anderson CB, N. T. (2007). The impact of child care providers' feeding on children's food consumption. J Dev Behav Pediatr, 28(2),

100-107. 10.1097/01.DBP.0000267561.34199 .a9.

Indira, I. A. (2015). Perilaku Konsumsi Sayur dan Buah Anak Prasekolah di Desa Embatu Kecamatan Tikala Kabupaten Toraja Utara. Jurnal MKMI, 253-262. https://media.neliti.com/media/publi cations/212713-perilaku-konsumsisayur-dan-buah-anak-pr.pdf.

Karaki, K. B. (2016). Hubungan Pola Asuh Ibu dengan Perilaku Sulit Makan pada Anak Usia Prasekolah (3-5 Tahun) di Taman Kanak-Kanak Desa Paleton Kecamatan Mofoinding Minahasa Selatan. Ejournal Keperawatan (E-Kp), 4(1). https://media.neliti.com/media/publi cations/108762-ID-hubungan-polaasuh-ibu-dengan-perilaku-s.pdf.

Kelder SH, Perry CL, Klepp KI, L. L. (1994). Longitudinal tracking of adolescent smoking, physical activity, and food choice behaviors. Am J Public Health, 84(7), 1121$1126 . \quad$ https://doi.org/: 10.2105/AJPH.84.7.1121

Khomsan Ali, dkk. 2008. T. P. P. G. D. (2008). Teknik Pengukuran Pengetahuan Gizi.

Lien N, Lytle LA, K. K. (2001). Stability in consumption of fruit, vegetables, and sugary foods in a cohort from age 14 to age 21. Prev Med, 33(3), 217-226.

Loya, Risani Rambu Podu., dan N. (2017). Pola Asuh Pemberian Makan pada Balita Stunting Usia 612 Bulan di Kabupaten Sumba Tengah Nusa Tenggara Timur. Journal of Nutrition College, 6(1), .83-95.

https://media.neliti.com/media/publi cations/200664-pola-asuhpemberian-makan-pada-bayi- 
stun.pdf

Lwin MO, Malik S, Ridwan H, A. C. (2017). Media exposure and parental mediation on fast-food consumption among children in metropolitan and suburban Indonesia. Asia Pac J Clin Nutr. 2017, 26(5). doi: 10.6133/apjen.122016.04. PMID: 28802300.

Miller V, Yusuf S, Chow CK, Dehghan M, Corsi DJ, Lock K, Popkin B, Rangarajan S, Khatib R, Lear SA, Mony P, Kaur M, Mohan V, Vijayakumar K, Gupta R, Kruger A, Tsolekile L, Mohammadifard N, Rahman O, Rosengren A, Avezum A, Orlandini A, Ismail N, LopezJara, M. A. (2016). Availability, affordability, and consumption of fruits and vegetables in 18 countries across income levels: findings from the Prospective Urban Rural Epidemiology (PURE) study. Lancet Glob Health, 2016 Oct;4. 10.1016/S2214-109X(16)30186-3.

Epub 2016 Aug 23. PMID: 27567348.

Moens E, Braet C, S. B. (2007). Observation of family functioning at mealtime: A comparison between families of children with and without overweight. $J$ Pediatr Psychol., 32(1), 52-63.

O'Connor TM, Hughes SO, Watson KB, Baranowski T, Nicklas TA, Fisher JO, Beltran A, Baranowski JC, Qu H, S. R. (2010). Parenting practices are associated with fruit and vegetable consumption in pre-school children. Public Health Nutrition, 13(1), 91-101. 10.1017/S1368980009005916..

Pujiyati, Retno., Kartini, F. (2010). Hubungan Pola Asuh Ibu dalam Pemberian Nutrisi dengan Status Gizi Balita Umur 1- 5 Tahun di Wilayah Puskesmas Temon Kecamatan Temon Kabupaten Kulon Progo Tahun 2010.

Putri, RM., Maemunah, N. (2017).
PENGETAHUAN

TENTANG

ANAK

SAYUR The Role of Education in Improving the Knowledge of Children about the Importance of Vegetables Asupan makanan yang bergizi memberikan manfaat yang sangat baik bagi pertumbuhan anak Makanan yang mengandung kalori. Jurnal Keperawatan, 8, 54-64.

Putri, RM., Susmini, S., \& Maemunah, N. (2020). (2020). Preferences (Attitudes and Preferences of Vegetables) of School Children Reviewed from knowledge. STRADA Jurnal Ilmiah Kesehatan, 9(1), 147-161. https://doi.org/10.30994/sjik.v9i1.23 3

Putri, R. M., Susmini, \& Hadi, H. S. (2017).

GAMBARAN PENGETAHUAN SAYUR ANAK USIA 5-12 TAHUN DI YAYASAN ELEOS INDONESIA DESA SUKODADI KECAMATAN WAGIR KABUPATEN MALANG. Jurnal Ilmu Keperawatan, 5(1), 7480. https://doi.org/https://doi.org/

Putriana, MI., Putriana, M. (2010). Konsumsi Sayur dan Buah pada Anak Prasekolah Terkait dengan Pengetahuan Gizi dan Sikap Ibu [Diponegoro Semarang]. http://eprints.undip.ac.id/24883/

Ren Y, Li H, W. X. (2019). Family income and nutrition-related health: Evidence from food consumption in China. Soc Sci Med, 232, 58-76. 10.1016/j.socscimed.2019.04.016.

Epub 2019 Apr 25. PMID: 31071477.

Restianti, H. (2009). Menerapkan Budaya Hidup Sehat:Pola Makan dan Keseimbangan Gizi.

Rohan HH., dan S. S. (2013). Buku Ajar Kesehatan Reproduksi.

Santoso, S. (2013). Kesehatan dan Gizi.

Santrock, J. W. (2011). Psikologi Pendidikan.

Sarwono, S. W. (2010). Psikologi Remaja 
Edisi Revisi.

Sriwahyuni., Indriasari, R., Salam, A. (2013). Pola Konsumsi Buah dan Sayur Serta Asupan Zat Gizi Mikro dan Serat Pada Ibu Hamil di Kabupaten Gowa. Jurnal MKMI, 1 15, 1-15. http://repository.unhas.ac.id/bitstrea $\mathrm{m} /$ handle/123456789/5457/Jurnal MKMI.pdf? sequence $=1$

Tarigan, R. (2020). (2020). HUBUNGAN KESUKAAN DAN KESEDIAAN DENGAN KONSUMSI SAYUR DAN BUAH PADA REMAJA. Jurnal Ilmiah Keperawatan Imelda, 6(1), 36-43. https://doi.org/10.2411/jikeperawata n.v6i1.359

Tridhonanto, Ali., \& B. A. (2014). Mengembangkan Pola Asuh Demokratis.

Virlita, Virlita, et al. (2015). Perception Dietary Fiber Consumption Habits in Youth Junior and Senior High School City of Palembang in 2013. Jurnal Ilmu Kesehatan Masyarakat, 6(2), 74-82. https://www.neliti.com/publications/ 58008/perception-dietary-fiberconsumption-habits-in-youth-juniorand-senior-high-scho\#cite

Winastyo, Kumboyono S, E. (2013). Hubungan Pola Asuh Orangtua dengan Konsumsi Sayuran pada Anak Usia Prasekolah di TK Islam Terpadu As Salam Malang. Jurnal Kedokteran Universitas Brawijjaya, 2(3), 24-25.

Wong, L. D. (2008). Buku Ajar Keperawatan Pediantrik.

Wunga, AAT., Ardiyani, VM., Ahmad, Z. (2019). (2019). Gambaran Perilaku Konsumsi Sayur Anak Pra Sekolah di TK Dharma Wanita Landungsari Kecamatan DAU Kabupaten Malang. Nursing News: Jurnal Ilmiah Keperawatan, 4(2).

Yumni, Dienny Zata., dan Wijayanti, H. S. (2017). Perbedaan Perilaku Makan dan Pola Asuh Pemberian
Makan antara Balita Gemuk dan Balita Non Gemuk di Kota Semarang. Journal of Nutrition College, 6(1), 43-51. https://media.neliti.com/media/publi cations/200607-perbedaan-perilakumakan-dan-pola-asuh-p.pdf. 